\title{
Визначення хронотипів системи травлення осіб, які займаються фітнесом, для забезпечення оптимального режиму їх харчування
}

\author{
Л. Ф. Оксамитна
}

Національний університет фізичного виховання і спорту України, Київ, Україна

\begin{abstract}
Резюме. По результатам анализа научной и научно-методической литературы разработана тестовая методика и тест-анкета определения хронотипа системы пищеварения для лиц, занимающихся фитнесом, и при проведении физической реабилитации как составляющей оздоровительных фитнес-программ. При натурном исследовании у лиц, занимающихся фитнесом, выявлены дневной и четкий вечерний хронотипы системы пищеварения. Установлено, что тестовая методика позволяет определять хронотипы системы пищеварения лиц, занимающихся фитнесом, и имеет высокую степень прямой корреляции системы пищеварения с биоритмологией дневной трудоспособности. В перспективе такая тестовая методика может быть использована для определения хронотипа системы пищеварения при организации питания лиц, занимающихся фитнесом, и при проведении физической реабилитации как составляющей оздоровительных фитнес-программ.
\end{abstract}

Ключевые слова: хронотип, биоритмы, фитнес, система, пищеварение.

\begin{abstract}
Summary. Based on the data of analysis of scientific and methodical literature testing approach and testing questionnaire were developed to determine chronotype of digestive system for people involved in fitness classes or in physical rehabilitation as a part of health and fitness programs. Field studies revealed in people involved in fitness classes day and clear evening chronotypes of digestive system. It was found that the developed testing approach allows determining chronotype of digestive system in persons involved in fitness, and has a high degree of direct correlation between digestive system and biorhythmology of day performance. In the long view, developed testing approach can be used to determine the chronotype of digestive system for management of nutrition for persons engaged in fitness classes and during physical rehabilitation as a part of health and fitness programs. Key words: chronotype, biorhythms, fitness, system, digestion.
\end{abstract}

Постановка проблеми. В сучасному фрітнесі та при проведенні фрізичної реабілітації як складової оздоровчих фітнес-програм велике значення має вирішення проблеми правильного, адекватного харчування. Суттєвою складовою цієї проблеми $є$ необхідність у врахуванні хронотипів травної системи при організації харчування осіб, які займаються фрітнесом, та при проведенні фрізичної реабілітації як складової оздоровчих фрітнес-програм. Від цього суттєво залежить вирішення важливого практичного завдання, а саме - досягнення ефрективності занять фрітнесом та проведення фрізичної реабілітації для покращення і збереження здоров'я людини [3, 4, 13, 16, 19, 22].

В методологічному аспекті у ролі критеріальних показників біоритмології організму людини майже завжди використовують характеристики циркадіанних біоритмів (від 20 до 28 год). Як інтегральний показник, що характеризує особливості біоритмології організму людини, найчастіше на практиці застосовують визначення хронотипу за переважним розташуванням у часі активної фрази біологічного ритму «сон-активність»: ранковий («жайворонки»), проміжний («голуби»), вечірній («сови»). При цьому 
важливо зазначити, що у людини як соціально-біологічного виду активна фаза біологічного ритму «сон-активність» припадає в основному на денний (світловий) період доби, на відміну від більшості видів ссавців, у яких активна фраза приурочена переважно до присмеркового та нічного періодів. У частини людської популяції дещо подібні види активної фрази біоритмології організму існують у вигляді ранкового та вечірнього типу активності (діяльності) [1, 5, 7, 8-11, 13, 16, 23-25].

Циркадіанні біологічні ритми має і система травлення: виділення слини, секреторна діяльність підшлункової залози, моторика шлунку та кишечнику тощо. Хронотип системи травлення може суттєво впливати на особливості харчової поведінки людини та ступінь її адекватності, на фрормування стереотипу харчової поведінки, на режим харчування. Тому цей хронотип має бути обов'язково врахований при визначенні правильного режиму харчування, при фрормуванні правильної (адекватної) харчової поведінки. Біологічним же індикатором біоритмів (біоритмології) системи травлення, який «сигналізує» у часовому режимі про готовність організму до вживання їжі (та відповідно процесу травлення), $€$ відчуття голоду (наявність апетиту) [1, 13, 18-21].

Bсе це має суттєве значення для визначення режиму харчування осіб, що займаються фрітнесом, та при проведенні фрізичної реабілітації як складової частини оздоровчих фрітнес-програм, а також для розподілу у часі протягом доби режимів тренування та вживання їжі.

Проте ще не розроблено тестової методики визначення хронотипу системи травлення для таких осіб, тому ми вважаємо дослідження цієї теми дуже актуальним.

Зв'язок 3 науковими планами, темами. Роботу виконано за НДР «Розробка системи оздоровчого харчування для осіб, які займаються фрітнесом» (№ держреєстрації 001U001736).

Мета дослідження - розробка тестової методики визначення хронотипу системи травлення осіб, що займаються фрітнесом, та при проведенні фрізичної реабілітації як складової частини оздоровчих орітнес-програм.

Основні завдання роботи:

- на основі аналізу та узагальнення даних наукової та науково-методичної літератури з проблеми врахування біоритмів системи травлення при організації харчування розробити тестову методику визначення хронотипу системи травлення для осіб, які займаються фітнесом, та при проведенні фрізичної реабілітації як складової оздоровчих фрітнес-програм;
- провести апробацію в реальних умовах розробленої тестової методики визначення хронотипу системи травлення для осіб, які займаються фрітнесом.

Методи та організація дослідження. Використано: метод теоретичного аналізу, який оснований на узагальненні, синтезі, екстраполяції і аналізі наукової і науково-методичної інформації [2]; тестова методика О. Остберга у модифрікації С. І. Степанової для визначення типу денної працездатності [5]; метод визначення рангового коефріцієнту кореляції Спірмена [14].

При організації дослідження використовували системний аналіз, узагальнення матеріалів наукової та науково-методичної літератури з питань біоритмів (біоритмології) системи травлення людини, щоб на цій основі розробити тестову методику визначення хронотипу системи травлення для осіб, які займаються фрітнесом, та при проведенні фрізичної реабілітації як складової оздоровчих фітнес-програм. Натурні дослідження 3 апробації роботи тестової методики мали на меті визначення хронотипу системи травлення для осіб, які займаються фрітнесом. Вони включали проведення тест-анкетування 100 осіб вікової групи 18-25 років (як найбільш чисельної серед відвідувачів сучасних фітнес-центрів, по 50 осіб чоловічої та жіночої статі), які займаються фрітнесом, для визначення хронотипів їх денної працездатності та системи травлення. Чисельність осіб для проведення натурного дослідження було визначено згідно з рекомендаціями Всесвітньої організації охорони здоров'я (ВОО3) стосовно необхідної кількості при проведенні натурних досліджень та спостережень [14].

Результати дослідження та їх обговорення. Відповідно до проведеного аналізу наукової та науково-методичної літератури, найчастіше на практиці хронотип людини визначають за рівнем денної працездатності (діяльності) - активної фрази біологічного ритму «сон-активність» протягом доби. Різниця в цьому перебігу біологічного ритму дозволяє визначати такі основні хронотипи: ранковий («жайворонки»), вечірній («сови») та найбільш поширений - проміжний - денний («голуби»), за аналогією за назвою $з$ особливостями добової (циркадіанної) біоритмології у різних видів птахів. У хронотипу «голуби» пік (максимум) добової активності припадає на середину денного (світлового) періоду, у хронотипу «сови» він посунутий на більш пізні години у порівнянні 3 хронотипом «голуби», а у хронотипу «жайворонки» - на більш ранні. Такі особливості періодичності у різних хронотипів пов'язують насамперед з різницею у швидкості 
зміни секреції гормонів (мелатоніна, кортізола тощо) $[5,7,8,12,18]$.

Хронотипи системи травлення протягом доби мають такий вигляд. Для чітко виражених «жайворонків» (ранковий хронотип) потреба у сніданку найчастіше відчувається в перші години після пробудження, а пік активності системи травлення зміщений у часі з середини дня у бік ранку. У чітко виражених «сов» (вечірній хронотип) така потреба відчувається у більшості випадків тільки через 1,5-2 год після пробудження, а пік активності системи травлення зміщений у часі з середини дня у бік вечора. Взагалі чітко виражені «сови», як правило, обідають та вечеряють пізніше чітко виражених «жайворонків» на 1,52,5 год. У «голубів» (перехідний, денний хронотип) пік активності системи травлення припадає на середину дня $[1,5,6,10,13,18,19]$.

Проте при цьому виникла проблема необхідності визначення хронотипу системи травлення для встановлення правильного, адекватного розподілу у часі прийомів їжі (насамперед сніданок, обід, вечеря) стосовно осіб з чітко вираженими хронотипами «жайворонки» та «сови», у яких динаміка у часі активності системи травлення суттєво відрізняється від тієї, що має місце у найбільш поширеного хронотипу - «голуби». Крім того, в окремих випадках можуть виникати прояви десинхронізації між біоритмами травної системи 3 біоритмами інших органів та систем організму серцево-судинної та м'язової систем - внаслідок різної стійкості біоритмів до дії зовнішніх чинників, при зміні часових поясів і та ін., а також через виникнення проявів десинхронізації з біоритмологією денної працездатності людини, що дуже суттєво стосовно практики занять з фітнесу та при проведенні фрізичної реабілітації [8, 13, 19].

В методологічному аспекті визначення хронотипу людини проводиться найчастіше за оцінкою денної працездатності 3 використанням спеціально розроблених тестових методик і застосуванням спеціальних тест-анкет, наприклад, за тестовою методикою О. Остберга в модифікації С. І. Степанової [5]. Отримані за такими тестовими методиками дані вже почали застосовувати в хрономедицині, хронофрармакології, хронобіології і та ін. [5, 6, 9, 15, 18].

Основою для проведення такого тестування $€$ визначення у часі ступеня готовності до працездатності. Тип денної працездатності визначається за сумою балів: чітко виражений ранковий тип (понад 92 бали); проміжні типи - слабко виражений ранковий (77-91 бал), аритмічний (58-76 балів), слабко виражений вечірній (42-57 балів); чітко виражений вечірній тип (до 41 бала) [5].
Проте у такого типу тестових методиках не передбачене визначення хронотипів системи травлення.

Нами було розроблено тестову методику визначення хронотипу системи травлення осіб, які займаються фрітнесом, та при проведенні фрізичної реабілітації як складової оздоровчих фрітнеспрограм з використанням спеціальної тест-анкети з бальною оцінкою результатів.

Науковою аргументацією стосовно обгрунтування методології тестової методики визначення хронотипу системи травлення у цих випадках $€$ необхідність визначення у часі піку активної фази процесу «потреба у їжі - відсутність потреби у їжі»: використання як біоіндикатора біоритмології системи травлення появи відчуття голоду (i відповідно - наявності апетиту); визначення ступеня необхідності (у часі) вживання напоїв стимулюючого типу дії (чаю, кави і та ін.) уранці після пробудження (ранковий період доби); вживання їжі у значній кількості пізно увечері (вечірній період доби).

Крім того, запропонована методика (у методологічному аспекті) має бути сумісною (мати високу ступінь прямої кореляції) 3 методиками визначення хронотипів денної працездатності.

Тестовою методикою передбачена можливість виділення 3 усієї сукупності контингенту осіб, які займаються фрітнесом, та при проведенні фрізичної реабілітації як складової оздоровчих фрітнес-програм, людей не тільки 3 хронотипу «голуби», але й з чітко вираженим за біоритмологією системи травлення хронотипів «сови» та «жайворонки» (за умов їх наявності серед контингенту обстежених).

У методологічному аспекті за тестовою методикою з використанням тест-анкети найбільша кількість балів нараховується для чітко вираженого ранкового хронотипу системи травлення (зааналогією з тестовою методикою визначення типу денної працездатності відносно хронотипу чітко вираженої ранкової працездатності для можливості подальшого співставлення отриманих за тестовими методиками даних) з наступним зниженням величини бальної оцінки для проміжного (денного) та чітко вираженого вечірнього хронотипів.

До тест-анкети входили такі запитання:

- який у вас апетит протягом першої години після пробудження: дуже сильний - 3; доволі сильний -2 ; доволі слабкий -1 ; дуже слабкий або відсутній - 0 ;

- якому сніданку ви віддаєте перевагу протягом першої години після пробудження: дуже щільному - 3; щільному - 2; незначної щільності - 1; достатньо соку та ін. -0 ; 
- від чого вам легше відмовитися: від ранкової чашки чаю (кави) - 3; від денної чашки чаю (кави) - 2; від вечірньої чашки чаю (кави) - 1; мені однаково - 0;

- легко вам змінити звички, пов'язані з часом приймання їжі: важко - 3; легко - 2; дуже легко - 1; не змінюю - 0 ;

- чи є у вас потреба у спеціальному вживанні протягом першої години після пробудження напоїв стимулюючого типу дії (чаю, кави і та ін.): потреби немає - 3; дуже незначна потреба -2 ; незначна потреба - 1; сильна потреба - 0;

- чи відчуваєте ви систематично потребу у вживанні їжі в значних кількостях пізно увечері: потреби немає - 3; дуже незначна потреба -2 ; незначна потреба - 1; сильна потреба - 0 .

Потрібне підкреслюється, та визначається загальна кількість балів.

При розподілі балів на три групи відповідно хронотипам системи травлення (ранковий, проміжний, вечірній) виходили 3 положення, що проміжний (денний - як основний режим активності людини) хронотип (відповіді проміжного характеру за тест-анкетою з оцінкою 2-1 бали) складає у сумі 12-6 балів від максимальної оцінки за тест-анкетою, яка становить 18 балів (всі шість відповідей за максимальною оцінкою у 3 бали). Таким чином, ранковий хронотип системи травлення складає у сумі 18-13 балів, проміжний 12-6 балів, вечірній - 5 балів і нижче.

Було проведено натурне дослідження з апробації дієвості тестової методики з визначенням хронотипу системи травлення осіб вікової групи 18-25 років, які займаються фітнесом, та їх зіставлюваності. Паралельно проводилось і визначення біоритмології денної працездатності 3 використанням тестової методики О. Остберга у модифрікації С. І. Степанової [5].

У більшої частини обстежених - у 85,0 \% був виявлений проміжний хронотип денної працездатності, а саме аритмічний хронотип (64,3 $\pm 3,1$ бала), а у $15,0 \%$ - чітко виражений вечірній (38,1 \pm 1,1 бала). Чітко вираженого ранкового хронотипу денної працездатності, не зафріксовано.

\section{Література}

1. Агаджанян Н. А. Хронофизиология, хронофрармакология и хрономедицина/ Н. А. Агаджанян. - Волгоград: Изд-во ВолГМУ, 2005. - 332 с.

2. Басков А. Я. Методология научного исследования / А. Я. Басков, Н. В. Туленков - К.: МАУП, 2004. - 215 с.

3. Василенко М. М. Сучасний стан та проблеми підготовки фрітнес-тренерів у США / М. М. Василенко // Педагогіка, психологія та медико-біологічні проблеми фрізичного виховання і спорту. - 2011. - №11. - С. 19-22.

4. ВоробьеВа В. И. Организация оздоровительного питания / В. И. Воробьева. - М.: Медицина, 2002. - 450 с.
Було встановлено, що у 84,0 \% обстежених мав місце проміжний (денний) хронотип системи травлення (8,4 \pm 0,3 бала), а у 16,0 \% - чітко виражений вечірній $(4,8 \pm 0,5$ бала), чітко вираженого ранкового хронотипу системи травлення не встановлено.

Проте у однієї особи чоловічої статі були зафріксовані певні прояви десинхронізації між біоритмами денної працездатності (проміжний, а саме аритмічний хронотип - 66 балів) та біоритмами системи травлення (чіткий вечірній хронотип - 3 бали).

Проведена оцінка ступеня кореляції між біоритмологією системи травлення та біоритмологією денної працездатності із застосуванням рангового коефіцієнтаСпірменапоказалависокийступіньпрямого кореляційного зв'язку $r=0,85$ ( $p<0,05)$. Це вказує на достатню сумісність розробленої тестової методики визначення хронотипу системи травлення для осіб, що займаються фітнесом, з тестовою методикою визначення добової працездатності, яку було використано в натурному дослідженні.

\section{Висновки}

На основі проведеного аналізу наукової та науково-методичної літератури було розроблено тестову методику визначення хронотипу системи травлення для осіб, що займаються фітнесом, та при проведенні фрізичної реабілітації як складової оздоровчих фрітнес-програм.

При проведенні натурного дослідження було встановлено, що розроблена тестова методика дозволяє визначати хронотипи системи травлення для осіб, які займаються фрітнесом, і має високий ступінь прямої кореляції отриманих за допомогою даних з визначення біоритмів травної системи за результатами оцінки біоритмів денної працездатності.

У перспективі подальші дослідження будуть спрямовані на розробку питань безпосереднього врахування хронотипу системи травлення при організації харчування осіб, які займаються фітнесом, та при проведенні фрізичної реабілітації як складової оздоровчих фрітнес-програм.

\section{References}

1. Ahadzhanian N. A. Chronophysiology, chronopharmacology and chronomedicine / N. A. Ahadzhanian. Volgograd: Publ. House VolGMU, 2005. - 332 p.

2. Baskov A. Ya. Methodology of scientific research / A. Ya. Baskov, N. V. Tulenkov. - Kiev: IAPM, 2004. - 215 p.

3. Vasilenko N. M. Current state and problems of fitness-trainers preparation in the U. S. / N.M. Vasilenko // Pedagogy, psychology and medical-biological problems of physical education and sport. - 2011. - N 11. - P. 19-22.

4. Vorobiova V. I. Management of healthy nutrition / V. I. Vorobiova. - Moscow: Medicine, 2002. - 450 p. 
5. Бардов В. Г. Загальна гігієна та екологія людини: підручник / В. Г. Бардов, І. В. Сергета. - Вінниця: Нова книга, 2002. - С. 185-203.

6. Бродин Д. В. Суточные изменения показателей иммунологического статуса смешанной слюны здоровых женщин / Д. В. Бродин // Вестн. Рос. ун-та дружбы народов. Сер.: медицина. - 2012. - № 7. - С. 57.

7. Загускин С. Л. Ритмы клетки и здоровье человека / С. Л. Загускин. - Ростов н/Д: НФУ, 2010. - 292 с.

8. Загускин С. Л. Биорезонанс, биосинхронизация, биуправление / С. Л. Загускин // Вестн. Рос. ун-та дружбы народов. Сер. Медицина. - 2012. - № 7. - С. 99.

9. Заславская Р. М. Хронофармакология и хрономедицина как новый методологический поход к оптимизации лечения / Р. М. Заславская, Л. Б. Васькова, Ю. Р. Болецновская // Пространство и время. - 2012. - №1. C. $195-198$.

10. Кашмина E. О. Хронобиология и физическое воспитание студентов/ Е. О. Кашмина, Ю. Л. Веневцева, А. Х. Мельников / / Вестн. Рос. ун-та дружбы народов. Сер. Медицина. - 2012. - №7. - С. 124.

11. Келина Н. Ю. Экология человека / Н. Ю. Келина, Н. В. Безручко. - М.: Феникс, 2009. - 400 с.

12. Стресс (хрономедицинские аспекты); под ред. Л. Г. Хетагуровой. - Владикавказ: Проект-Пресс, 2010. - 192 с.

13. Лебедев Н. Н. Биоритмы пищеварительной системы / Н. Н. Лебедев. - М.: Медицина, 1987. - 256 с.

14. МамаеВ А. Н. Основы медицинской статистики: учебн. пособие / А. Н. Мамаев. - М.: Медицина, 2011. - 128 с.

15. Неудахин E. В. Обоснование хронобиологического подхода к назначению лекарственных препаратов при различных заболеваниях у детей / Е. В. Неудахин // Практика педиатра. - 2012. - № 3. - С. 15-19.

16. Хильденбрант Г. Хронобиология и хрономедицина / Г. Хильденбрант, М. Максимилиан, Л. Лихофер. - М.: Арнебин, 2006. - 144 с.

17. Хоули Э. Т. Руководство инструктора оздоровительного фитнеса / Э. Т. Хоули, Дон Фрэнкс. - К.: Олимп. лит., 2004. - 375 с.

18. Хронобиология и хрономедицина: [руководство]; под ред. С. И. Рапопорта, В. А. Фролова, Л. Г. Хетагуровой. - М.: МИА, 2012. - 480 с.

19. Цыганенко О. И. Концепция системы оздоровительного (функционального) питания в фритнесе // Педагогіка, психологія та медико-біол. проблеми фріз. виховання і спорту. - 2011. - № 5. - С. 107-110.

20. Цыганенко О. И. Проблема неадекватного (девиантного) пищевого поведения лиц, занимающихся фритнесом, и при проведении физической реабилитации как составляющей оздоровительных фитнес - программ, пути ее решения / [О. И. Цыганенко, Я. В. Першегуба, О. Л. Паладина, Н. А. Склярова и др. ] // Физ. воспитание студентов. 2013. - № 2. - С. 63-68.

21. Шапошникова В. И. Хронобиология и спорт / В. И. Шапошникова, В. А. Таймазов. - М.: Сов. спорт, 2005. - 177 c.

22. Шурыгина $A$. В. Основные принципы хронотерапии: научн.-метод. пособие для врачей / [А. В. Шурыгина, Ю. И. Бородин, В. А. Труфакин, Т. И. Новоселов]. - Новосибирск: Изд-во СО РАМН, 2002. - 208 с.

23. Arendt G. Melatonin as chronobiotic / G. Arendt, D. I. Skene // Sleep. Med. Rev. - 2005. - Vol. 9, N 1. - P. 25-39.

24. NSCA - CPT Job Analysis Committee. NSCA - CPT Content Description Manual, Lincoln, NE: NSCA Certification Commission, 2001. - 100 p.

25. Orlock $C$. Inner time: The science of body clocks and what makes us tick / C. Orlock. - Birch Lane Press, 1993. $-76 \mathrm{p}$.
5. Bardov V. G. General hygiene and ecology of human: textbook / V. G. Bardov, I. V. Serheta. - Vinnitsa: Nova Kniga, 2002. - P. 185-203.

6. Brodin D. V. Diurnal changes in the immune status of mixed saliva in healthy women / D. V. Brodin // Vestnik Rossiiskogo Universiteta Druzhby narodov. Series: Medicine. - 2012. - N 7. - P. 57.

7. Zaguskin S. L. Cellular rhythms and human health / S. L. Zaguskin. - Rostov-on-Don: NFU, 2010. - 292 p.

8. Zaguskin S. L. Bioresonance, biosynchronization, biomanagement / S. L. Zaguskin // Vestnik Rossiiskogo Universiteta Druzhby narodov. Series: Medicine. - 2012. N 7. - p. 99.

9. Zaslavskaia R. M. Chronopharmacology and chronomedicine as a new methodological approach to optimize the treatment / R. M. Zaslavskaia, L. B. Vaskova, Yu. R. Boletsnovskaya // Prostranstvo i vremia. - 2012. - N 1. - P. 195-198.

10. Kashmina Ye. O. Chronobiology and physical education for students / Ye. O. Kashmina, Yu.L. Venevtseva, A. Kh. Melnikov // Vestnik Rossiiskogo Universiteta Druzhby narodov. Series: Medicine. - 2012. - N 7. - P. 124.

11. Kelina N. Yu. Human ecology / N. Yu. Kelina, N. V. Bezruchko. - Moscow: Phoenix, 2009. - 400 p.

12. Stress(chronomedicalaspects):Monograph /Ed.L.G. Khetagurova. - Vladikavkaz: Proekt-Press, 2010. - 192 p.

13. Lebedev N. N. Biorhythms of digestive system / N. N. Lebedev. - Moscow: Medicine, 1987. - 256 p.

14. Mamaiev A. N. Basics of medical statistics: study guide / A. N. Mamaiev. - Moscow: Medicine, 2011. - 128 p.

15. Neudakhin Ye. V. Substantiation of chronobiological approach to drug prescription for treatment various diseases in children / Ye. V. Neudakhin // Pediatric practice. 2012. - N 3. - P. 15-19.

16. Hildenbrant G. Chronobiology and chronomedicine / G. Hildenbrant, M. Maximilian, L. Lihofer. - Moscow: Arnebin, 2006. - 144 p.

17. Howley E. T. Health fitness instructor's handbook / E. T. Howley, D. Franks. - Kiev: Olympic Literature, 2004. $375 \mathrm{p}$.

18. Chronobiology and chronomedicine. [manual]; ed. by S. I. Rapoport, V. A. Frolova, L. G. Khetagurova. - Moscow: MIA, 2012. - 480 p.

19. Tsyganenko $O$. I. The concept of health improving (functional) nutrition in fitness // Pedagogy, psychology and medical-biological problems of physical education and sport. - 2011. - N 5. - P. 107-110.

20. Tsyganenko O. I. The problem of inadequate (deviant) eating behavior in people involved in fitness classes and during physical rehabilitation as a part of health and fitness programs, and its solution / [O. I. Tsyganenko, Ya.V. Persheguba, O. L. Paladina, N. A. Skliarova et al.] // Fizicheskoe vospitanie studentov. - 2013. - N 2. - P. 63-68.

21. Shaposhnikova V. I. Chronobiology and sport / V. I. Shaposhnikova, V. A. Taimazov. - Moscow: Soviet Sport, 2005. - 177 p.

22. Shurygina A. V. Basic principles of chronotherapy: method. manual for physicians / [A. V. Shurygina, Yu. I. Borodin, V. A. Trufakin, T. I. Novoselov]. - Novosibirsk: Publ. House of SB RAMS, 2002. - 208p.

23. Arendt G. Melatonin as chronobiotic / G. Arendt, D. I. Skene // Sleep. Med. Rev. - 2005. - Vol. 9, N 1. P. $25-39$.

24. NSCA - CPT Job Analysis Committee. NSCA - CPT Content Description Manual, Lincoln, NE: NSCA Certification Commission, 2001. - 100 p.

25. Orlock $C$. Inner time: The science of body clocks and what makes us tick / C. Orlock. - Birch Lane Press, 1993. $-76 \mathrm{p}$. 